\title{
アモルファス金属錯体法を用いた $\left(\mathrm{Ca}_{\mathrm{x}} \mathrm{La}_{1-\mathrm{x}}\right)\left(\mathrm{Ba}_{1.75-\mathrm{x}} \mathrm{La}_{0.25+\mathrm{x}}\right) \mathrm{Cu}_{3} \mathrm{O}_{7+\delta}$ の合成之 キャラクタリゼーション
}

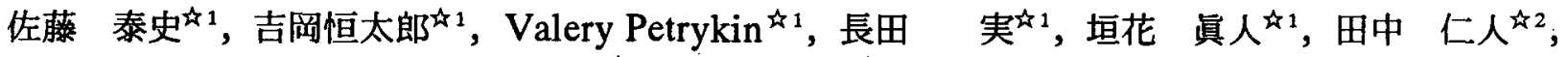
山口愛放, 勝又 隆玄圤, 安岡宏放

\1 東京工業大学応用セラミックス研究所，干 226-8503 横浜市緑区長津田町 4259 .

4 2 防衛大学校応用物理学科, $\bar{T} 239-8686$ 横須賀市走水 1-10-20.

\section{Synthesis and Characterization of $\left(\mathrm{Ca}_{\mathrm{x}} \mathrm{La}_{1-\mathrm{x}}\right)\left(\mathrm{Ba}_{1.75-\mathrm{x}} \mathrm{La}_{0.25+x}\right) \mathrm{Cu}_{3} \mathrm{O}_{7+\delta}$ Tetragonal Superconductor by an Aqueous Solution Technique Using Citric Acid}

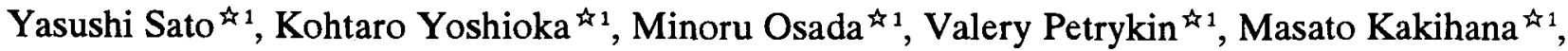 \\ Yoshito Tanaka $^{\text {出 }}$, Ai Yamaguchi ${ }^{\text {t2 }}$, Takahiro Katsumata ${ }^{\text {th }}$ and Hiroshi Yasuoka ${ }^{\text {t } 2}$ \\ " 1 Materials and Structures Laboratory, Tokyo Institute of Technology, 4259 Nagatsuda Midori-ku, Yokohama 226-8503. \\ '2 2 Depertament of Applied Physics, The National Defense Academy, 1-10-20 Hashirimizu, Yokosuka 239-8686.
}

Received August 6, 2001

\section{SYNOPSIS}

Polycrystalline samples of $\left(\mathrm{Ca}_{\mathbf{x}} \mathrm{La}_{1-x}\right)\left(\mathrm{Ba}_{1.75-\mathrm{x}} \mathrm{La}_{025+\mathrm{x}}\right) \mathrm{Cu}_{3} \mathrm{O}_{7+\delta}$ tetragonal superconductor for $\mathrm{Ca}$ content $(\mathrm{x})$ from 0.0 to 0.6 were synthesized by a simple aqueous solution technique using citric acid. The combined results of X-ray diffraction and Raman scattering analysis indicated that the polycrystalline samples for the entire Ca content $(x)$ were of single-phase character. The $T_{c}$ onset values for $(\mathrm{x})$ from 0.0 to 0.6 , determined precisely from the complex magnetic susceptibility measurements, increased from $45.0 \mathrm{~K}$ for $\mathrm{x}=0.0$ to $78.7 \mathrm{~K}$ for $\mathrm{x}=0.4$, remained almost constant at $80 \mathrm{~K}$ between $\mathrm{x}=0.5$ and $\mathrm{x}=0.6$. It was also found that sintering condition affected rather dramatically superconducting properties in this system.

KEY WORDS

cuprate superconductor, Raman scattering, amorphous citric acid method, gel, carrier concentration, doping, sintering condition

\section{1 緒 言}

$90 \mathrm{~K}$ 級 $\mathrm{YBa}_{2} \mathrm{Cu}_{3} \mathrm{O} 7-\delta$ は $\mathrm{P}$ 型超伝導体であり，2種類の $\mathrm{Cu}$ サ イト $\left(\mathrm{CuO}_{2}\right.$ 面と $\mathrm{Cu}$ 鎖サイト $)$ と $\mathrm{Y}^{3+} や \mathrm{La}^{3+}$ といった希土類か 主に占める希土類サイト，そして $\mathrm{Ba}^{2+}$ が主に占める $\mathrm{Ba}$ サイト からの構造をとる.この物質の超伝導特性については， $\mathrm{Cu}$ 鎖 部分の酸素量に応じて $\mathrm{CuO}_{2}$ 面上へのホールキャリアが変化す る事が知られており, 酸素量 $(\boldsymbol{d})$ が 7 の場合, 超伝導転移温度

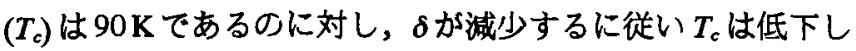
て行き， $\delta$ が約 6.4 付近で非超伝導体となる ${ }^{1)}$.このように酸 素量の変化による $\mathrm{CuO}_{2}$ 面へのキャリアの導入に関する研究は これまで数多く報告されているが，酸素量を正確に制御する ためのアニール条件や酸素量の決定方法に多くのテクニック を必要とする゙゚.これに対して,この系では金属元素を異なる 原子価のもので置換する事でホール量を変化させる事も可能 である。例えば， $\mathrm{Y}^{3+}$ をオン半径の近い $\mathrm{Ca}^{2+}$ で置換した場 合, 電荷補償によりホールを生みだし，結果的に $\mathrm{CuO}_{2}$ 面中の
キャリア濃度を增加させる ${ }^{3)}$. 逆に $\mathrm{Ba}^{2+}$ を $\mathrm{La}^{3+}$ で置換した場 合には，電荷補償により電子が生じ，キャリア濃度を減少さ せる゙ .このように試料作製の段階で酸素を均一に試料へ導入 できれば, カチオン置換のみで系のホールキャリアを制御す る事が可能になり，酸素量制御による方法より正確かつ容易 な方法だといえる.

$\left(\mathrm{Ca}_{x} \mathrm{La}_{1-x}\right)\left(\mathrm{Ba}_{1.75-x} \mathrm{La}_{0.25+x}\right) \mathrm{Cu}_{3} \mathrm{O}_{7+\delta}(\mathrm{CLBCO})$ は $\mathrm{YBCO}$ 系酸化物 超伝導体の類似物質であり， $\mathrm{Ca}^{2+}$ が $\mathrm{Y}$ サイト単独に， $\mathrm{La}^{3+}$ が YおよびLaサイトそれそれに置換する正方晶酸化物超伝導体 である ${ }^{5,9}$. 既往の固相法による研究では, $\mathrm{Ca}(\mathrm{x})=0.5$ まで単相 試料の作製が可能であるとされており， $T_{\mathrm{c}}$ は $\mathrm{Ca}=0.0 \sim 0.5$ の 間で 40〜80 K まで上昇する5).つまり，この系は，希土類サ イトに $\mathrm{Ca}^{2+}$ と $\mathrm{La}^{3+}$ が同時に占有する事で電荷補償によりホー ルを生成させる事ができるため, カチオンの仕込み組成によ る $\mathrm{CuO}_{2}$ 面中のホール濃度の調整が可能になる.

本研究では,この系におけるカチオンドービングと $\mathrm{CuO}_{2}$ 面 
上のキャリア濃度との相関を調査するための前段階として， この系の高純度試料の作製方法について検討を行った。作製 方法には，均一な多元素系複合酸化物の合成方法として知ら れるアモルファス金属錯体法 ${ }^{7.8)}$ をいて，Caドープ量 $(\mathrm{x})$ が 0.0〜0.6までの均一な試料の合成を試みた.そして, 作製した 試料について，従来のXRDに加え，超伝導体中の不純物を检 出するのに優れた能力を持つラマン分光法") と超伝導転移温 度 $\left(T_{c}\right)$ の決定以外にも目的外の超伝導物質の検出に対しても 有効な交流複素帯磁率法 ${ }^{10}$ を用いて試料の均一性を確認した。 また，試料純度に対して焼成条件が及ほす影響についても調 查した.

\section{2 試料及ひ実験方法}

$\mathrm{La}_{2} \mathrm{O}_{3}, \mathrm{CaCO}_{3}, \mathrm{BaCO}_{3}, \mathrm{CuCO}_{3}-\mathrm{Cu}(\mathrm{OH})_{2}$ を出発原料とし, そ れらを目的組成に応じて秤量した後, $120^{\circ} \mathrm{C}$ のットプレー 卜上で加熱したクエン酸水溶液 ( $300 \mathrm{ml}$ ビーカを使用) に溶解 させた.この時の水溶液の組成比仗, [金属: クエン酸: 水]= [1:7:40]である. 原料粉末を完全に溶解させた後，ホットブ レート温度を $150^{\circ} \mathrm{C}$ まで上げ，液量が約 $100 \mathrm{mI}$ 以下になるま で保持した. その後 $200^{\circ} \mathrm{C}$ まで上げ, ゲル化させた後, マン トルヒーターにより約 $450^{\circ} \mathrm{C} て ゙$ 加熱し灰化させた. 得られた 灰化した試料は粉砕し，さらに電気炉により $600^{\circ} \mathrm{C} て ゙ 12$ 時間 焼成し非晶質前駆体とした. 続いて，この前駆体をアルミナ ボートにのせ，空気中 $900^{\circ} \mathrm{C} て ゙ 10$ 時間仮焼成を行った. 試料 粉末はペレット状に成型した. その後, 酸素雾囲気中 910 $950^{\circ} \mathrm{C} て ゙ 24$ 時間本焼成し, 続けて $1^{\circ} \mathrm{C} / \mathrm{min}$ の速度で $400^{\circ} \mathrm{C}$ ま で降温させた後, その状態で 24 時間アニーリングを行った. 得られた試料の生成相の同定には，マックサイエンス社製

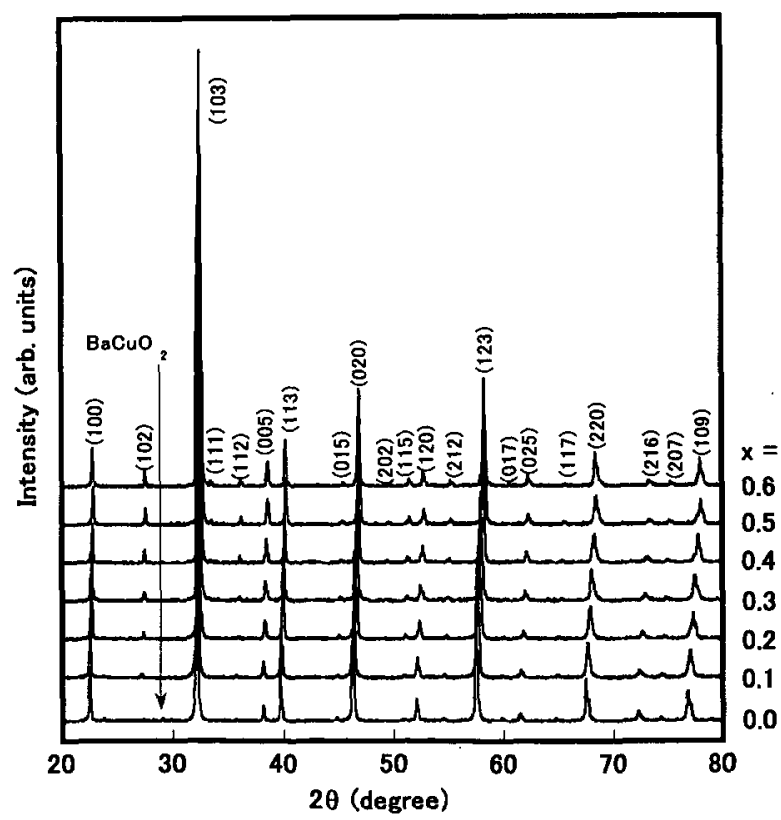

Fig.1 X-ray diffraction patterns of $\left(\mathrm{Ca}_{\mathrm{x}} \mathrm{La}_{1.00-\mathrm{x}}\right)\left(\mathrm{Ba}_{1.75-\mathrm{x}} \mathrm{La}_{0.25+\mathrm{x}}\right)$ $\mathrm{Cu}_{3} \mathrm{O}_{7+\delta}$ polycrystalline samples with $\mathrm{x}=0.0-0.6$ prepared by amorphous citrate method.
$\mathrm{MXP}^{3 \mathrm{VA}}$ 粉末 $\mathrm{X}$ 線回折装置を用いた.さらにラマンスペクトル の測定については, Jobin-Yvon/愛宕物産社製T64000ラマンシ ステムを使用した. 試料の超伝導特性の評価と試料中の超伝 導的な不純物の検出に対しては，Hartshornブリッジ10)を用い た交流複素帯磁率測定装置を用いて行った。

\section{3 実験結果及ひ考察}

アモルファス金属錯体法により合成した $\mathrm{x}=0.0 \sim 0.6$ までの $\left(\mathrm{Ca}_{\mathrm{x}} \mathrm{La}_{1-\mathrm{x}}\right)\left(\mathrm{Ba}_{1.75-\mathrm{x}} \mathrm{La}_{0.25+x}\right) \mathrm{Cu}_{3} \mathrm{O}_{7+\delta}$ の粉末 $\mathrm{X}$ 線回折パターンを Fig.1に示す. $\mathrm{Ca}=0.0$ において, 極微量の $\mathrm{BaCuO}_{2}$ 不純物と考 えられるピークがステップスキャンにより観測されているも のの,これ以外の試料においては $\mathrm{Ca}_{2} \mathrm{CuO}_{3} や \mathrm{BaCuO}_{2}$ といった 不純物の存在》 は観察されず, 正方晶の $\mathrm{YBa}_{2} \mathrm{Cu}_{3} \mathrm{O}_{7-\delta}$ と同じ $\mathrm{XRD}$ プロファイルであった. 格子定数は $\mathrm{Ca}$ 量の増加に応じ て隇少しており，特にc 軸長ではほほ直線的に変化した。こ れは,イオン半径の小さいC $\mathrm{Ca}^{2+}$ 希土類サイトへ選択的に置 換した結果と考えられる.さらに微量の不純物の存在を確認 するため, $\mathrm{Ca}(\mathrm{x})=0.0 \sim 0.6$ 試料粉末のマクロラマンスペクト 儿測定を行った. 一般にラマン分光法では, 金属的伝導を持 つ物質より，半導体的あるいは絶縁体的な物質の振動モード を検出し易い9. そのため, 今回予想されるような絶縁体不純 物を検出に対しては，非常に有効な方法であるといえる。 Fig.2に各組成のラマンスペクトルを示す. $\mathrm{Ca}(\mathrm{x})=0.1 \sim 0.6$ の 試料のラマンスペクトルについては不純物として予想される $\mathrm{Ca}_{2} \mathrm{CuO}_{3}$ に起因したピークやシフトは観察されず，これらの 試料が単相であると判断する事できる. 以上の事より,アモ ルファス金属錯体法を用いた本研究では， $\mathrm{Ca}$ の固溶限を従来 の $\mathrm{x}=0.5$ から 0.6 付近まで拡大する事に成功したと考えられ る。一般に幅広い固溶域を実現するには，構成する金属イオ

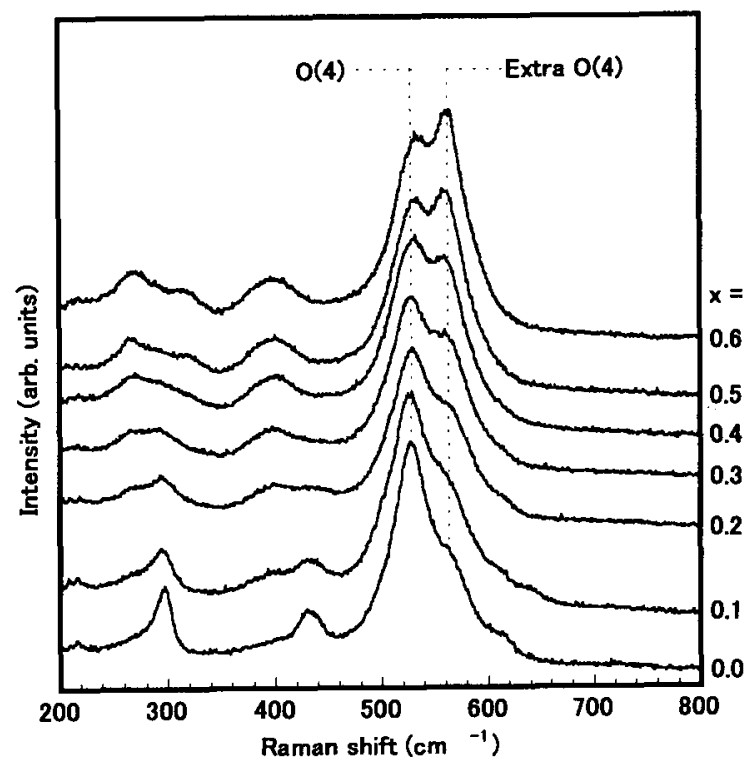

Fig.2 Raman spectra of $\left(\mathrm{Ca}_{\mathrm{x}} \mathrm{La}_{1.00-\mathrm{x}}\right)\left(\mathrm{Ba}_{1.75-\mathrm{x}} \mathrm{La}_{0.25+\mathrm{x}}\right) \mathrm{Cu}_{3} \mathrm{O}_{7+\delta}$ polycrystalline samples with $\mathrm{x}=0.0-0.6$ prepared by amorphous citrate method. 
ンの混合状態を高める必要がある. 通常の金属イオンの拡散 を利用した固相反応法の場合では，高温 $\left(1000^{\circ} \mathrm{C}\right.$ 以上)での焼 成を必要とするが，YBCO系のような酸化物超伝導体では固 溶体を形成するより先に溶融分解を起こしてしまい, 単相試 料を得る事が非常に困難である。これに対して，アモルファ ス金属錯体法で合成した試料は，すでに前駆体の時点で高い 金属イオンの混合状態が達成されている事が期待される.そ のため, 本来 YBCO系の適切な焼成温度とされる $900^{\circ} \mathrm{C}$ 付近 においても，従来の固相法であるならば実現不可能であった 組成の固溶体の合成が可能になったものと考えられる.

$\mathrm{Ca}=0.0$ については, XRD 結果に反し, 約 $640 \mathrm{~cm}^{-1}$ 付近に $\mathrm{BaCuO}_{2}$ のモ一ドが明瞭に現れている8,1112). 過去のLa123系固 溶体の研究によると, Ba量の多い組成については, 高酸素雾 囲気中で作製した場合，Baサイトに La+ 系固溶体と $\mathrm{BaCuO}_{2}$ の混相になる ${ }^{11}$. 本研究はすべての組成に ついて酸素雾囲気中で焼成したため, $\mathrm{Ba}$ 量の多い $\mathrm{Ca}=0.0$ で は, 上記のような事態が生じたものと推測できる.そのため, 空気中で本焼成を行った後, 窒素雾囲気中で $600^{\circ} \mathrm{C}, 15$ 時間 アニーリングし,さらに酸素雾囲気中で $400^{\circ} \mathrm{C}, 48$ 時間アニー リングを行った. その結果, この試料については, $\mathrm{BaCuO}_{2}$ フ リーの単相試料である事が確認できた (Fig.3).

ところでFig.2に示す各組成のラマンスペクトルでは, $\mathrm{Ca}$ 量 の增加に伴いCu鎖一頂点酸素(Cu(1)-O(4))の結合に起因する $535 \mathrm{~cm}^{-1}$ のモードの相対強度が減少するのに对し, $565 \mathrm{~cm}^{-1}$ 付近 に新しいモードの相対強度の増加が確認できる ${ }^{13)}$.このモー ドは，Baサイトに置換した $\mathrm{La}^{3+}$ か頂点酸素 $\mathrm{O}(4)$ を変位させ た事により出現した別の頂点酸素モードと帰属できる ${ }^{13,14}$.

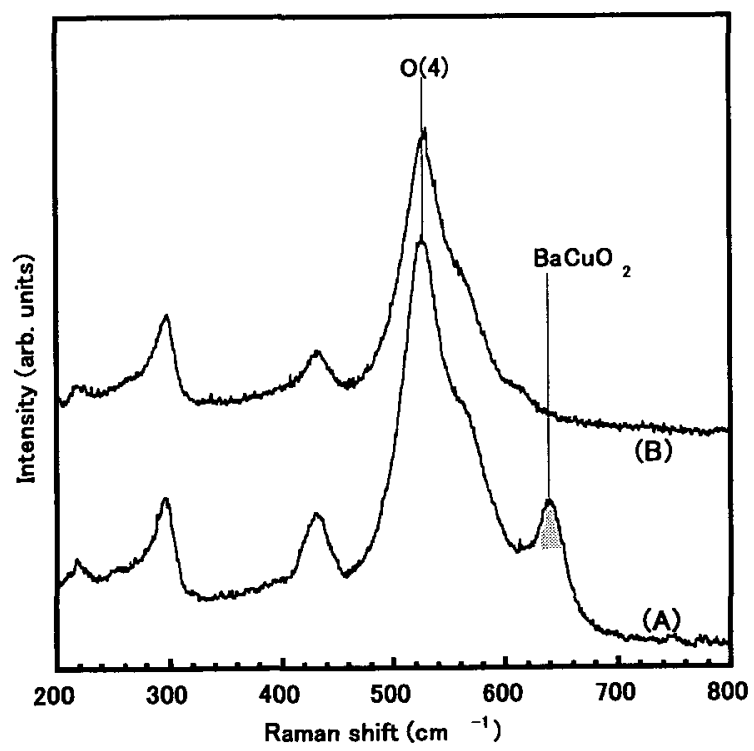

Fig.3 Raman spectra of $\left(\mathrm{Ca}_{\mathbf{x}} \mathrm{La}_{1.00-x}\right)\left(\mathrm{Ba}_{1.75-x} \mathrm{La}_{0.25+x}\right) \mathrm{Cu}_{3} \mathrm{O}_{7+\delta}$ polycrystalline samples with $\mathrm{x}=0.0$ polycrystalline samples, where (A) was sintered and annealed under oxygen atmosphere, (B) was sintered under air, and then annealed under nitrogen and oxygen atmosphere. The trace of $\mathrm{BaCuO}_{2}$ appears in (A).
CLBCO系では, $\mathrm{Ca} / \mathrm{Ba}$ 比率の変化により組成を変化させるた め, $\mathrm{La}$ 量は全組成域でも一定量であるため, $\mathrm{Ca}^{2+}$ が希土類サ イトに選択的に置換した場合, $\mathrm{La}^{3+}$ は $\mathrm{Ca}^{2+}$ 量と同じ量だけ Ba サイトに置換する事になる。このため, $565 \mathrm{~cm}^{-1}$ 付近に現れる 新しいモードの強度は, 結果的として Baサイト中の $\mathrm{La}^{3+}$ 濃度 を表している ${ }^{13)}$.

複素帯磁率測定では，超伝導転移温度 $\left(T_{c}\right)$ を決定する他に， 超伝導試料の均一性を見る事も可能である.例としてFig.4に 焼成条件の異なる $\mathrm{Ca}=0.4 の$ 複素帯磁率測定結果を示す.ここ で実数部 $X_{1}^{\prime}$ はMeissner効果および超伝導電流による磁気遮蔽 効果を表し，虚数部 $\chi^{\prime \prime}$ は，ヒステリシス損失を表している ${ }^{10}$. 仮に試料中に複数の超伝導相が存在した場合, $x_{1}^{\prime}$ 曲線はそれ に対応し複数の転移曲線が重なり合ったものになり, $\chi^{\prime \prime}{ }_{1}$ 曲線 上にも複数のピークが出現する. $950^{\circ} \mathrm{C}, 8$ 時間で本焼成した 試料の $x_{1}^{\prime}$ は不連続な転移を示し, $x^{\prime \prime}{ }_{1}$ 曲線は大きく分けて 2 つ のピークが現れている.この事はこの試料中には 2 種類の超 伝導相の存在を意味している ${ }^{10}$. これに対し, $910^{\circ} \mathrm{C}, 8$ 時間 で焼成した試料の $x_{1}^{\prime}$ 曲線は非常にシャープな転移を示してお $\eta$, 完全反強磁性への転移温度幅 $\left(\Delta T_{\mathrm{c}}(10 \sim 90 \%)\right)$ は $2 \mathrm{~K}$ 以内 であった. また メ" ${ }_{1}$ 曲線は 1 本の鋭いピークのみ現れていた. つまりこの結果は, $910^{\circ} \mathrm{C} て ゙$ 焼成した試料か超伝導的に単相 試料である事を示している.

試料中に 2 種類以上の超伝導体が含まれる理由として, 次 の事が考えられる.Fig.5に Fig.4の試料のラマンスペクトル を示すが,ここで $950^{\circ} \mathrm{C} ， 8$ 時間で焼成した試料には約 $610 \mathrm{~cm}^{-1}$ 付近にピークが現れている.このピークは, $\mathrm{Cu}$ 鎖一酸素に起 因したモードであり，Cu鎖周りの酸素に欠陥が生しる際に現 れる事が知られており ${ }^{11,12,15)}$ ，この状態での $T_{c}$ は本来の值より も低下する. $950^{\circ} \mathrm{C} て ゙$ 焼成した試料では，比較的高い焼成温 度により結晶粒が大きく成長し(光学顕微鏡での観察によると 5〜10 $\mu \mathrm{m}$ 程度であった), その結果, 試料への酸素の均一な抎

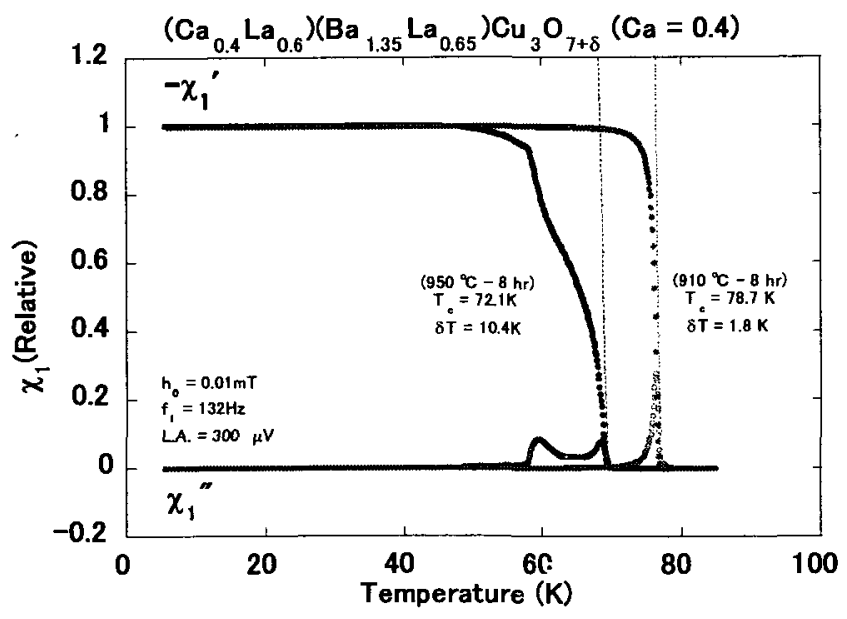

Fig.4 Real and imaginary components of the complex magnetic susceptibility $\chi_{1}^{\prime}$ and $\chi^{\prime \prime}{ }_{1}$ versus temperature $T$ for $\left(\mathrm{Ca}_{0.40} \mathrm{La}_{0.6}\right)\left(\mathrm{Ba}_{1.35} \mathrm{La}_{0.65}\right) \mathrm{Cu}_{3} \mathrm{O}_{7+\delta}$ polycrystalline samples sintered at 910 and $950^{\circ} \mathrm{C}$, where $\mu_{0} \mathrm{H}_{\mathrm{AC}}=0.01 \mathrm{mT}$ and $f=$ $132 \mathrm{~Hz}$. Data are normalized by mass. 


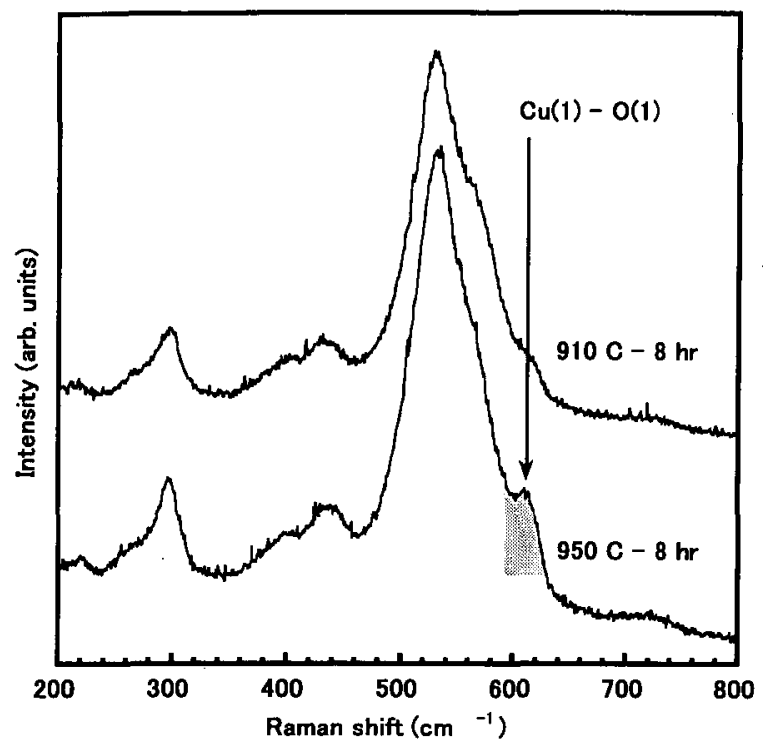

Fig.5 Raman spectra of $\left(\mathrm{Ca}_{0.40} \mathrm{La}_{0.6}\right)\left(\mathrm{Ba}_{1.35} \mathrm{La}_{0.65}\right) \mathrm{Cu}_{3} \mathrm{O}_{7+\delta}$ polycrystalline samples sintered at 910 and $950^{\circ} \mathrm{C}$.

散が起こりづらくなった事が予想できる，そのため，試料中 にCu鎖周りの酸素不均一を生じた領域が出現し，この領域か 本来の低い $T_{c}$ を持つ超伝導相として振る舞う事が理由として

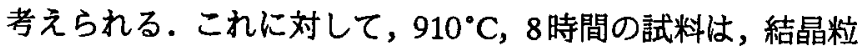
は約 $1 \mu \mathrm{m}$ 程度と比較的小さい粒から構成されており，そのス ペクトルには Cu鎖の酸素欠陥に起因するモードは見られな かった.よって，910でて焼成した試料については，Cu鎖周 りの酸素はある程度均一に分布しており，超伝導相として振 る舞うような酸素不均一な領域は存在しないと考えられる. このように適切な焼成条件を選ぶ事により，Cu鎖周りの酸素 の不均一を防止し，超伝導的にも単相化できる事が明らかに なった.

$\mathrm{Ca}=0.0 \sim 0.6$ までの超伝導転移温度 $\left(T_{c}\right)$ を Fig. 6 に示す. $T_{c}$ 值は, $\mathrm{Ca}$ 量 $(\mathbf{x})$ が 0.0 〜 0.4 まで增加するに従い $45.0 \mathrm{~K}$ から $78.7 \mathrm{~K}$ まで上昇し， $\mathrm{x}=0.5 \sim 0.6$ において約 $80 \mathrm{~K}$ 一定であった. $\mathrm{Ca}^{2+} / \mathrm{La}^{3+}$ の置換により生成したホールが, 超伝導体の舞台となる $\mathrm{CuO}_{2}$ 面に注入された結果と考えられる.また，ここで得られた $T_{c}$ 值は, 既往の研究 ()のものより向上しており, 試料の均一性 が向上した事に起因するものと考えられる.

\section{4 ま とめ}

本研究では前駆体合成法としてアモルファス金属錯体法を 用い，さらに適切な焼成条件を選択し， $\left(\mathrm{Ca}_{\mathbf{x}} \mathrm{La}_{1-\mathrm{x}}\right)\left(\mathrm{Ba}_{1.75-\mathrm{x}}\right.$ $\left.\mathrm{La}_{025+x}\right) \mathrm{Cu}_{3} \mathrm{O}_{7+\delta}$ 系酸化物超伝導体の合成を試みた。 その結果， 得られた超伝導体試料は，XRDおよびラマン分光法，複素帯 磁率法より，高純度単相試料である事が確認された。ささらに 既往の研究と比べCa置換量を $\mathrm{x}=0.6$ まで拡張する事に成功し た. また，超伝導転移温度 $\left(T_{c}\right)$ は Ca 置換量の増加と共に增加 し, $x=0.5 \sim 0.6$ で最高点 $(80 \mathrm{~K})$ に達した. 今後, さらに Ca固

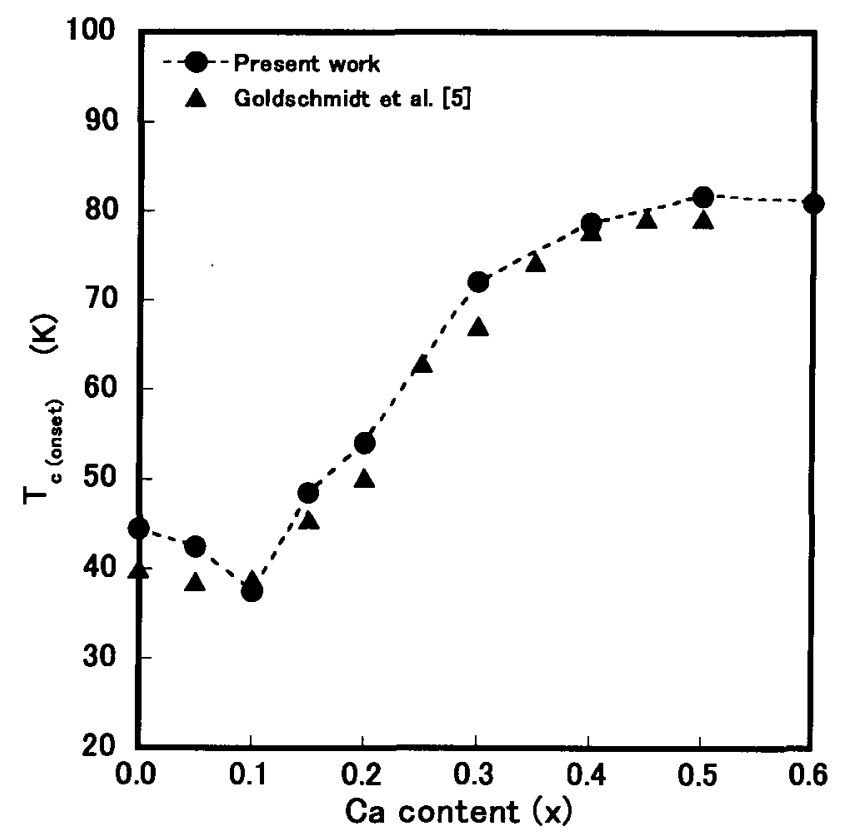

Fig.6 Dependence of $T_{c}$ vs. Ca content (x) in $\left(\mathrm{Ca}_{\mathbf{x}} \mathrm{La}_{1.00-\mathrm{x}}\right)\left(\mathrm{Ba}_{1.75-\mathrm{x}}\right.$ $\left.\mathrm{La}_{0.25+x}\right) \mathrm{Cu}_{3} \mathrm{O}_{7+\delta}$ polycrystalline samples from $\mathrm{x}=0.0$ to $\mathrm{X}=$ 0.6 made by amorphous citrate method.

溶限の拡張を検討し, より綿密な. $\mathrm{Ca}$ 置換量と $\mathrm{CuO}_{2}$ 面中の キャリア量との相関関係を明らかにしたいと考えている。

\section{謝辞}

本研究は, 文部科学省の科学研究費補助金 (13450264)の援 助を受けて行われました。

\section{文献}

1) R.J.Cava, A.W.Hewat, E.A.Hewat, B.Batlog, M.Marezio, K.m.Rabe, J.J.Krajewski, W.F.Peck, Jr. and L.W.Rupp, Jr.: "Structural anomalies, oxygen ordering and superconductivity in oxygen deficient $\mathrm{Ba}_{2} \mathrm{YCu}_{3} \mathrm{O}_{x}$ ", Physica C, 165(1990)419-433.

2) R.J.Cava, B.Batlogg, C.H.Chen, E.A.Ramirez, S.M.Zahurak and D.Werder: "Single-phase $60-\mathrm{K}$ bulk superconductor in annealed $\mathrm{Ba}_{2} \mathrm{YCu}_{3} \mathrm{O}_{y \neq \delta}(0.3<\delta<0.4)$ with correlated oxygen vacancies in the Cu-O chains", Phys. Rev. B, 36(1987)5719-5722.

3) K.Yoshimura, T.Kiyama and K.Kosuge: "Superconducting properties of the $\mathrm{La}_{1+x} \mathrm{Ba}_{2-\mathrm{x}} \mathrm{Cu}_{3} \mathrm{O}_{y}$ system", (Proceeding of ISS1994) Advances in Supercoductivity VI, 377.

4) R.J.Cava, B.Batlogg, R.M.Fleming, S.A.Sunshine and E.A.Ramirez: " $\mathrm{Ba}_{2-\mathrm{x}} \mathrm{La}_{\mathrm{x}} \mathrm{YCu}_{3} \mathrm{O}_{\mathrm{y} \pm \delta}$ perovskite compounds: Crystal chemistry", Phys. Rev. B, 37(1988)5912-5915.

5) D.Goldschmidt, G.M.Reisner, Y.Direktovitch, A.Kinzhnik, E.Gartstein, G.Kimmel and Y.Eckstein: "Tetragonal superconducting family $\left(\mathrm{Ca}_{x} \mathrm{La}_{1-x}\right)\left(\mathrm{Ba}_{1.75-x} \mathrm{La}_{0.25+x}\right) \mathrm{Cu}_{3} \mathrm{O}_{y}$ : "The efefect of cosubstitution on the transition temperature", Phys. Rev. B, 48(1993)532-542. 
6) D.Goldschmidt, A.Kinzhnik, Y.Direktovitch, G.M.Reisner and Y.Eckstein: "Variation of $T_{c}$ and resistivity in chargecompensated $\left(\mathrm{Ca}_{\mathrm{x}} \mathrm{La}_{1-\mathrm{x}}\right)\left(\mathrm{Ba}_{.75-\mathrm{x}} \mathrm{La}_{025+\mathrm{x}}\right) \mathrm{Cu}_{3} \mathrm{O}_{y}$ ", Phys. Rev. B, 49(1994)15928-15935.

7) M.Kakihana: "Sol-Gel preparation of high temperature superconducting oxide", J. Sol-Gel Sci. Technol., 6(1996)7-55.

8) M.Kakihana, S.Kato, V.Petrykin, J.Backstrom, L.Börjesson and M.Osada: "A simple and reproducible way to synthesize $\mathrm{PrBa}_{2} \mathrm{Cu}_{4} \mathrm{O}_{8}$ under $1 \mathrm{~atm}$ oxygen by amorphous citrate method", Physica C, 321(1999)74-80.

9) 垣花蕒人, 八島正知, 吉村昌弘: "ものづくりとスペクト ロスコピー,第 5 講 酸化物超伝導体をつくる一化学合成 とラマン散乱 ", 分光研究 , 43(1994)320-336.

10）間崎啓匡: "複素帯磁率による超伝導体の研究",粉体粉末 治金, 44(1988)811-816.

11) H.J.Rosen, R.M.Macfarlane, E.M.Engler, V.Y.Lee and
R.D.Jacowitz: "Systematic Raman study of effects of rare-earth substitution on the lattice modes of high- $T_{c}$ superconductors", Phys. Rev. B, 38(1988)2460-2465.

12) M.Kakihana, L.Börjesson, S.Eriksson, P.Svedlindh and P.Norling: "Raman spectra, superconductivity, and structure of Co-substituted $\mathrm{YBa}_{2} \mathrm{Cu}_{3} \mathrm{O}_{7-\delta}$ " Phys. Rev. B, 4O(1989)6787-6796.

13) K.Yoshioka, Y.Sato, V.Petrykin, M.Kakihana, Y.Tanaka, A.Yamaguchi and H.Yasuoka: unpublished.

14) N.Yoshida, R.Nishitani, Y.Sasaki and Y.Nishina: "Systematic Raman scattering study on substitutional effects in solid solution systems of $\mathrm{Ln}_{1+x} \mathrm{Ba}_{2-\mathrm{x}} \mathrm{Cu}_{3} \mathrm{O}_{y}(\mathrm{Ln}=\mathrm{Eu}, \mathrm{Sm}$ and $\mathrm{La}) "$, Jpn. J. Appl. Phys., 28(1989)1757-1759.

15) M.Kakihana, S.Eriksson, L.Börjesson, L.G.Johansson, C.Ström and M.Käll: "Charge-transfer and compression effects of isomorphous substitutions in $\mathrm{YBa}_{2} \mathrm{Cu}_{3} \mathrm{O}_{7}$ ", Phys. Rev. $\mathrm{B}, 47$ (1993)5359-5365. 